\title{
Sweetpotato Response to Simulated Glyphosate Wick Drip
}

\author{
Stephen L. Meyers, Katherine M. Jennings, and David W. Monks*
}

Field studies were conducted in 2009 at Clinton, NC and 2014 at Pontotoc, MS to determine the influence of simulated glyphosate drip on sweetpotato yield and quality. Treatments consisted of three glyphosate solution $\left(140 \mathrm{~g}_{\text {ae }} \mathrm{L}^{-1}\right)$ drip volumes $(0.16,0.32$ and $0.48 \mathrm{ml})$ by four application timings [( 4 wk after transplanting (WAP); 6 WAP; 8 WAP; and 4 WAP followed by (fb) 6 WAP fb 8 WAP]. A non-treated check was included for comparison. Visual sweetpotato injury consisted of chlorosis at the shoot tips approximately $1 \mathrm{wk}$ after treatment $\mathrm{fb}$ necrosis and stunting. At $6 \mathrm{WAP}$ and 8 WAP, sweetpotato injury following glyphosate applied 4 WAP was 71 and 65\%, respectively. Injury from glyphosate applied $4 \mathrm{WAP}$ fb $6 \mathrm{WAP}$ was 78\%. Injury from glyphosate applied 6 WAP was $26 \%$ at 8 WAP. In 2009, jumbo, no. 1, canner, and marketable yield of the non-treated check were two to three times greater than glyphosate treatments $(0.16,0.32,0.48 \mathrm{ml})$. Likewise, yield of the non-treated check was substantially greater than those treated with 0.16 to $0.48 \mathrm{ml}$ glyphosate solution in 2014. In 2009 and 2014, sweetpotato yield of all grades increased as glyphosate application timing was delayed. In 2009 , no. 1 yield from glyphosate 8 WAP $\left(8,210 \mathrm{~kg} \mathrm{ha}^{-1}\right)$ was similar to the non-treated check. In 2009, there were no cracked storage roots in the non-treated check. However, sweetpotatoes receiving 0.16 to $0.48 \mathrm{ml}$ glyphosate solution displayed 8 to $17 \%, 11$ to $18 \%, 5$ to $13 \%$, and 11 to $16 \%$ cracking (by weight) in jumbo, no. 1 , canner, and marketable storage roots, respectively. Compared to the non-treated check, glyphosate applied $4 \mathrm{WAP}, 6 \mathrm{WAP}$, or $4 \mathrm{WAP} \mathrm{fb} 6 \mathrm{WAP} \mathrm{fb} 8 \mathrm{WAP}$ had a greater percentage of cracked marketable sweetpotato storage roots.

Nomenclature: Glyphosate; sweetpotato, Ipomoea batatas L. Lam.

Key words: Root cracking, off-target, storage root.

\begin{abstract}
Estudios de campo fueron realizados en 2009 en Clinton, North Carolina y en 2014 en Pontotoc, Mississippi para determinar la influencia de goteo simulado con glyphosate sobre el rendimiento y la calidad de la batata. Los tratamientos consistieron de tres volúmenes de goteo $(0.16,0.32$, y $0.48 \mathrm{ml})$ de solución de glyphosate $\left(140 \mathrm{~g}^{2} \mathrm{~L}^{-1}\right)$ y cuatro momentos de aplicación [4 semanas después del trasplante (WAP); 6 WAP; 8 WAP; y 4 WAP seguido por (fb) 6 WAP $\mathrm{fb} 8 \mathrm{WAP}$. Un testigo sin tratamiento fue incluido para fines de comparación. El daño visualmente estimado de la batata consistió de clorosis en los ápices del tejido aéreo de la batata aproximadamente 1 semana después del tratamiento fb necrosis y crecimiento atrofiado. A 6 WAP y 8 WAP, el daño en la batata después de la aplicación de glyphosate 4 WAP fue 71 y 65\%, respectivamente. El daño causado por glyphosate aplicado 4 WAP fb 6 WAP fue $78 \%$. El dańo con glyphosate aplicado 6 WAP fue 26\% a 8 WAP. En 2009, los rendimientos jumbo, no. 1, canner, y comercializable del testigo sin tratamiento fueron dos a tres veces mayores que los tratamientos con glyphosate $(0.16,0.32$, y $0.48 \mathrm{ml})$. De la misma manera, el rendimiento del testigo sin tratamiento fue sustancialmente mayor que el de los tratamientos con glyphosate en soluciones desde 0.16 a $0.58 \mathrm{ml}$ en 2014 . En 2009 y 2014, los rendimientos de la batata para todos los grados de calidad aumentaron al retrasarse el momento de aplicación de glyphosate. En 2009, el rendimiento no. 1 después del glyphosate 8 WAP $\left(8,210 \mathrm{~kg} \mathrm{ha}^{-1}\right)$ fue similar al testigo sin tratamiento. En 2009 , no hubo raíces con fisuras por almacenamiento en el testigo sin tratamiento. Sin embargo, las batatas que recibieron de 0.16 a $0.48 \mathrm{ml}$ de solución de glyphosate mostraron 8 a 17\%, 11 a 18\%, 5 a 13\%, y 11 a 16\% de raíces con fisuras (en términos de peso) en raíces almacenadas de jumbo, no. 1, canner, y comercializables, respectivamente. En comparación con el testigo sin tratamiento, glyphosate aplicado 4 WAP, 6 WAP, o 4 WAP fb 6 WAP fb 8 WAP tuvo un mayor porcentaje de raíces de batata comercializables con fisuras.
\end{abstract}

\footnotetext{
DOI: 10.1614 /WT-D-16-00073.1

*First author: Assistant Extension Professor, Pontotoc Ridge-Flatwoods Branch Experiment Station, Mississippi State University, Pontotoc, MS 38863; Second and third authors: Assistant Professor and Professor, Department of Horticultural Science, North Carolina State University, Raleigh, NC 27695. Corresponding author's E-mail: stephen.meyers@msstate.edu
} 
In sweetpotato, yields are maximized by maintaining fields weed-free through vine closure, approximately 6 to $8 \mathrm{wk}$ after transplanting (WAP) (Seem et al. 2003). Sweetpotato producers in the southeastern United States rely heavily on a combination of PRE herbicides, between-row cultivation, and hand-removal to control weeds. POST weed control options in sweetpotato are limited (Kemble 2015). Clethodim, sethoxydim, and fluazifop are registered for use in sweetpotato to control emerged grasses. Glyphosate and carfentrazone-ethyl can be POST-directed between rows, however, POSTdirected applications in sweetpotato are difficult given the crop's decumbent growth habit. Weeds within the planted row often escape between-row cultivation. Although hand-removal and hoeing of broadleaf weeds is common in sweetpotato production systems, and many fields are hand-weeded at least once each season to control escaped weeds, hand-weeding is expensive and labor-intensive.

Studies conducted in North Carolina have demonstrated the potential use of wick-applicators for controlling Palmer amaranth (Amaranthus palmeri S. Wats.) in a salvage scenario in sweetpotato. Palmer amaranth is a common and troublesome weed in North Carolina sweetpotato production (Webster 2014). Coleman (2014) reported that paraquat applied in a cross-wick 6 or 7 WAP controlled Palmer amaranth $80 \%$ and $85 \%$, respectively, 15 WAP, resulting in marketable and no. 1 sweetpotato yields more than two times greater than that of a weedy check. Cross-wick applications of $d$-limonene [(4R)-1methyl-4-prop-1-en-2-ylcyclohexene] also improved sweetpotato yields compared to that of a weedy check, although Palmer amaranth control was limited to $12 \%$ to $32 \%$ at 15 WAP (Coleman 2014). Meyers et al. (2016) reported that glyphosate applied using a Dixie $^{\circledR}$ wick at 4 to 8 WAP resulted in greater sweetpotato yield than that of a weedy check, and that fields wicked at 7 WAP had greater than 90\% Palmer amaranth control 2 wk afterwards. Although glyphosate applied using a Dixie ${ }^{\circledR}$ wick improved sweetpotato yields relative to that of a weedy check, the investigators found that herbicide solution from the wicking implement can drip on sweetpotato foliage, possibly contributing to storage root cracking. The impact of this off-target herbicide exposure has not been investigated.

Off-target impacts of glyphosate on vegetable crops have been reported by others. Felix et al.
(2011) applied glyphosate to potato (Solanum tuberosum L.) at 8.5 to $423 \mathrm{~g}_{\text {ae }} \mathrm{ha}^{-1}$, and reported the greatest injury to potato plants treated at the hooking stage with $\geq 54 \mathrm{~g}$ ae $\mathrm{ha}^{-1}$. Similarly, Felix et al. (2012) reported increasing injury to flag-leaf, two-leaf, four-leaf, and six-leaf dry bulb onion (Allium cepa L.) plants as glyphosate rates increased from 8.6 to $860 \mathrm{~g}$ ae $\mathrm{ha}^{-1}$. Similarly, the yield of US no. 1 grade onions decreased with increasing glyphosate rate, and at one of two locations the most damage was observed when glyphosate was applied to onions at the four-leaf stage (Felix et al. 2012). Gilreath et al. (2000) applied glyphosate to pepper (Capsicum annuum L.) at flowering, after fruit set, and sequentially at flowering and after fruit set. They reported that peppers treated at flowering generally showed a greater reduction in marketable yield than those treated after fruit set, and that sequential applications resulted in the lowest marketable yield. Applications by Felix et al. $(2011 ; 2012)$ and Gilreath et al. (2000) were broadcast onto crop foliage with $\mathrm{CO}_{2}$-pressurized backpack sprayers. Santos et al. (2007) exposed fresh market tomato (Solanum lycopersicum L.) transplants to sublethal doses of glyphosate by submerging the foliage in glyphosate solution ( 0 to $200 \mathrm{mg} \mathrm{L}^{-1}$ ) $1 \mathrm{~d}$ before transplanting, and reported decreased plant vigor, height, and yield with increasing glyphosate concentration.

The objective of this study was to determine the effect of simulated glyphosate drip on sweetpotato, including changes in yield and storage root cracking.

\section{Materials and Methods}

Field studies were conducted in 2009 and 2014 to determine sweetpotato response to simulated glyphosate drip. To determine what glyphosate volumes to use in the study, 200 drops of water were collected from a standard Dixie ${ }^{\circledR}$ wick applicator (Dixie Wick Company, 5807 Highway 11 North, Grifton, NC) that leaked from the cotton canvas sleeves. The average drip volume observed was $0.08 \mathrm{~mL}$. Based on this observation, three glyphosate (Roundup WeatherMax ${ }^{\circledR}$, Monsanto Company, 800 North Lindbergh Boulevard, St. Louis, MO) solution drip volumes, $0.16,0.32$, and $0.48 \mathrm{~mL}\left(140 \mathrm{~g}\right.$ ae $\left.\mathrm{L}^{-1}\right)$; and four application timings, 4 WAP, 6 WAP, 8 WAP, and 4 WAP followed by 6 WAP followed by 8 WAP; were selected. A non-treated check

Meyers et al.: Glyphosate Drip on Sweetpotato • 131 
was included for comparison. In 2009, nonrooted 'Covington' sweetpotato vine cuttings (slips) were transplanted $30 \mathrm{~cm}$ apart into rows $106 \mathrm{~cm}$ apart on June 5 at the Horticultural Crops Research Station in Clinton, North Carolina $\left(35.0227^{\circ} \mathrm{N}\right.$, $78.2794^{\circ} \mathrm{W}$ ) into a Norfolk loamy sand (fine-loamy, siliceous, thermic Typic Paleudult) with a $\mathrm{pH}$ of 5.9 and $<1 \%$ humic matter. In 2014, 'Beauregard' sweetpotato slips were transplanted $30 \mathrm{~cm}$ apart into rows $1 \mathrm{~m}$ apart on July 7 at the Pontotoc RidgeFlatwoods Branch Experiment Station in Pontotoc, Mississippi $\left(34.1331^{\circ} \mathrm{N}, 89.0063^{\circ} \mathrm{W}\right)$ into a Falkner silt loam with a $\mathrm{pH}$ of 6.9 and $1.3 \%$ organic matter. Plots consisted of two rows; the second row of each plot was treated. All plots were maintained weed-free throughout the growing season by hand-removing emerged weeds weekly.

Treatments were applied to one newly expanded leaf located within the planted row for each sweetpotato plant using an adjustable pipetter (100 to $1,000 \mu \mathrm{L}$; Fisherbrand $^{\circledR}$ Finnipipette ${ }^{\circledR}$ II). The experimental design was a randomized complete block with five replications in 2009 and four replications in 2014. Data collected included visual estimates of crop injury on a scale of $0 \%$ (no injury) to $100 \%$ (crop death) 6, 8, and $10 \mathrm{WAP}$. Sweetpotatoes were harvested $17 \mathrm{WAP}$ using a chain digger, and were hand-graded based on their diameter into jumbo $(>8.9 \mathrm{~cm})$, no. $1(>4.4 \mathrm{~cm}$ but $\leq 8.9 \mathrm{~cm})$, and canner $(>2.5 \mathrm{~cm}$ but $\leq 4.4 \mathrm{~cm})$ (USDA 2005). Marketable yield was calculated as the sum of the jumbo, no. 1, and canner grade yields. After grading, storage roots exhibiting longitudinal cracking were separated and weighed, and the percentage of cracked roots by weight was determined for each grade.

Data were subjected to ANOVA by $\mathrm{SAS}^{\circledR}$ version 9.4 (SAS Institute Inc., 100 SAS Campus Drive, Cary, NC) Proc GLM with the fixed effects of glyphosate volume and application timing, and random effects of year and replication within year. When ANOVA indicated a significant volume and/ or timing effect, means were separated using Fisher's protected LSD $(\mathrm{P} \leq 0.05)$. Non-treated check plots were excluded from visual crop injury data analysis, but were included in sweetpotato yield and root cracking data analysis.

\section{Results and Discussion}

Sweetpotato Crop Tolerance. Due to a lack of glyphosate solution volume by application timing interaction, the effect of glyphosate solution volume was analyzed across application timings and the effect of application timing was analyzed across solution volumes. Due to a lack of treatment by year interaction, data were analyzed across 2009 and 2014. Approximately $1 \mathrm{wk}$ after treatment, plants displayed chlorosis at the growing points. By 2 wk after treatment, injury was apparent in the form of necrosis and overall plant stunting. At 6 WAP, injury from glyphosate applied 4 WAP was 71\% (data not shown). At 8 WAP, sweetpotatoes treated 4 WAP were $65 \%$ injured, and sweetpotatoes treated 4 and 6 WAP were $78 \%$ injured. Glyphosate applied 6 WAP resulted in only $26 \%$ injury at 8 WAP. By $10 \mathrm{WAP}$, sweetpotatoes in adjacent rows had grown into the treated rows, making visual injury ratings difficult to determine without disturbing the plots. Sweetpotato injury was not affected by solution volume. This result differs from those reported in other vegetable crops, where crop injury increased as glyphosate rate increased (Felix et al. 2011, 2012; Gilreath et al. 2000; McNaughton et al. 2012; Santos et al. 2007). The method of application utilized in the present study differed from other off-target glyphosate research in that applications were not made in a broadcast manner, and solution volume, not herbicide concentration, differed among treatments. Glyphosate solution was applied to a single sweetpotato leaf. Immediately after application, solution accumulating on the leaf surface rolled off the sweetpotato leaf and fell onto either sweetpotato leaves lower in the canopy or the soil.

Sweetpotato Yield. Sweetpotato yield data revealed a year by treatment interaction and were analyzed separately by year. Within year, there was no glyphosate solution volume by application timing interaction. Therefore, the effect of glyphosate solution volume was analyzed across application timings, and the effect of application timing was analyzed across solution volumes. In both 2009 and 2014, sweetpotato yield data revealed a significant response to simulated glyphosate drip volume and glyphosate drip timing.

Effect of Simulated Glyphosate Drip Volume. In 2009, the non-treated plots yielded 14,320; 9,420; 3,850 ; and $27,590 \mathrm{~kg} \mathrm{ha}^{-1}$ of jumbo, no. 1, canner, and marketable grade sweetpotatoes, respectively (Table 1). The storage roots of the plants in the nontreated plots enlarged quickly before harvest and had a greater proportion of jumbo-sized sweetpotatoes 
Table 1. Effect of simulated glyphosate drip volume on sweetpotato yield at Clinton, North Carolina in 2009 and Pontotoc, Mississippi in 2014 .

\begin{tabular}{|c|c|c|c|c|c|c|c|c|}
\hline \multirow[b]{3}{*}{ Drip volume $^{a}$} & \multicolumn{8}{|c|}{ Sweetpotato yield } \\
\hline & \multicolumn{2}{|c|}{ Jumbo } & \multicolumn{2}{|c|}{ No. 1} & \multicolumn{2}{|c|}{ Canner } & \multicolumn{2}{|c|}{ Marketable $^{\mathrm{b}}$} \\
\hline & 2009 & 2014 & 2009 & 2014 & 2009 & 2014 & 2009 & 2014 \\
\hline Non-treated & 14,320 & 1,870 & 9,420 & 17,110 & 3,850 & 4,270 & 27,590 & 23,250 \\
\hline 0.16 & 5,490 & 270 & 3,900 & 5,890 & 1,350 & 2,640 & 10,740 & 8,800 \\
\hline LSD $(\mathrm{P} \leq 0.05)$ & 2,740 & 720 & 1,610 & 5,310 & 470 & 1,610 & 3,980 & 6,690 \\
\hline
\end{tabular}

${ }^{\mathrm{a}}$ Glyphosate solution contained $140 \mathrm{~g}$ ae $\mathrm{L}^{-1}$.

b Marketable is the aggregate of jumbo, no. 1, and canner.

than did the treated plots. Jumbo, no. 1, canner, and marketable yields of the non-treated check $(0 \mathrm{~mL}$ glyphosate solution) were two to three times greater than were the yields in plots treated with 0.16 to $0.48 \mathrm{~mL}$ of glyphosate solution. In 2014, sweetpotato yield data trends were similar to 2009 . The non-treated check yielded 1,$870 ; 17,110 ; 4,270$; and $23,250 \mathrm{~kg} \mathrm{ha}^{-1}$ of jumbo, no. 1, canner, and marketable sweetpotatoes, respectively. As in 2009, the non-treated check had substantially greater yields of all sweetpotato grades than did the treated plots. Jumbo, no. 1 , and marketable yields of plots receiving glyphosate solution volumes of $0.16,0.32$, or $0.48 \mathrm{~mL}$ did not differ from one another. As was the case with crop injury, this result differs from those reported in other vegetable crops, in which crop yield decreased as glyphosate rate increased
(Felix et al. 2011, 2012; Gilreath et al. 2000; McNaughton et al. 2012; Santos et al. 2007).

Effect of Simulated Glyphosate Drip Timing. In both 2009 and 2014, sweetpotato yield of all grades increased as glyphosate application timing was delayed (Table 2). In 2009, no. 1 yield in sweetpotato treated at 8 WAP only $\left(8,210 \mathrm{~kg} \mathrm{ha}^{-1}\right)$ was statistically similar to that of the non-treated check. In 2014, canner yields in sweetpotato treated 6 or 8 WAP $\left(2,910\right.$ and $3,920 \mathrm{~kg} \mathrm{ha}^{-1}$, respectively) were similar to that of the non-treated check. Sequential glyphosate applications reduced yields of all grades compared to that of the non-treated check, and sweetpotato receiving a single application of glyphosate at 4,6 , or 8 WAP. This result is similar to the findings of Gilreath et al. (2000), who reported that marketable

Table 2. Effect of simulated glyphosate drip timing on sweetpotato yield at Clinton, North Carolina in 2009 and Pontotoc, Mississippi in 2014 .

\begin{tabular}{|c|c|c|c|c|c|c|c|c|}
\hline \multirow[b]{3}{*}{ Drip timing $^{a}$} & \multicolumn{8}{|c|}{ Sweetpotato yield } \\
\hline & \multicolumn{2}{|c|}{ Jumbo } & \multicolumn{2}{|c|}{ No. 1} & \multicolumn{2}{|c|}{ Canner } & \multicolumn{2}{|c|}{ Marketable $^{\mathrm{b}}$} \\
\hline & 2009 & 2014 & 2009 & 2014 & 2009 & 2014 & 2009 & 2014 \\
\hline Non-treated & 14,310 & 1,870 & 9,420 & 17,110 & 3,850 & 4,270 & 27,580 & 23,250 \\
\hline 4 & 1,690 & 150 & 1,220 & 3,820 & 790 & 1,510 & 3,700 & 5,480 \\
\hline $4 \mathrm{fb} 6 \mathrm{fb} 8$ & 100 & 0 & 520 & 1,050 & 410 & 1,620 & 1,030 & 2,670 \\
\hline $\operatorname{LSD}(\mathrm{P} \leq 0.05)$ & 2,830 & 750 & 1,660 & 5,530 & 490 & 1,684 & 4,110 & 6,970 \\
\hline
\end{tabular}

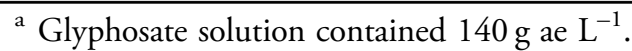

b Marketable is the aggregate of jumbo, no. 1, and canner.

c Abbreviations: fb, followed by; WAP, weeks after transplanting.

Meyers et al.: Glyphosate Drip on Sweetpotato • 133 
pepper yields decreased more with sequential glyphosate applications than they did with a single application made at flowering or after fruit set.

Sweetpotato tolerance relative to application timing varies by herbicide. Meyers et al. (2013) reported that sweetpotato tolerance to $S$-metolachlor increased between 0 and $14 \mathrm{~d}$ after transplanting (DAP). Sweetpotato tolerance to POST applications of thifensulfuron (MacRae et al. 2007a) and trifloxysulfuron (MacRae et al. 2005) increased as application timing was delayed from 1 to 8 WAP. Similarly, MacRae et al. (2007b) reported that halosulfuron-methyl applications at 4 WAP did not reduce no. 1 or total yields of Beauregard and 'Hernandez' sweetpotato. However, applications made less than 4 WAP reduced no. 1 and/or total yields. Simulated off-target flumioxazin applications at 2 or 5 WAP resulted in sweetpotato yields similar to one another and lower than the non-treated check (Meyers et al. 2014).

Sweetpotato Storage Root Cracking. Sweetpotato storage root cracking data were found to have a year by treatment interaction and were analyzed separately by year. Root cracking in 2014 was not influenced by either glyphosate solution volume or application timing (data not shown). In 2009, sweetpotato storage roots in the non-treated check had $0 \%$ cracking incidence (Tables 3 and 4). Sweetpotatoes receiving 0.16 to $0.48 \mathrm{~mL}$ glyphosate solution displayed $8 \%$ to $17 \%, 11 \%$ to $18 \%, 5 \%$ to $13 \%$, and $11 \%$ to $16 \%$ cracking in jumbo, no. 1 , canner, and marketable storage roots, respectively (Table 3). Cracked storage root percentage was similar among all sweetpotatoes treated with 0.16 to $0.48 \mathrm{~mL}$ glyphosate solution. Felix et al. (2011) reported growth

Table 3. Effect of simulated glyphosate drip volume on sweetpotato storage root cracking injury at Clinton, North Carolina in 2009.

\begin{tabular}{lrrrc}
\hline & \multicolumn{4}{c}{ Percent of yield cracked (by weight) } \\
\cline { 2 - 5 } Drip volume $^{\mathrm{a}}$ & Jumbo & No. 1 & Canner & Marketable $^{\mathrm{b}}$ \\
\hline $\mathrm{mL}$ & 0 & 0 & 0 & 0 \\
Non-treated & 17 & 11 & 13 & 16 \\
0.16 & 11 & 18 & 6 & 15 \\
0.32 & 8 & 11 & 5 & 11 \\
0.48 & $\mathrm{NS}$ & 15 & 11 & 11 \\
LSD $(\mathrm{P} \leq 0.05)$ &
\end{tabular}

${ }^{a}$ Glyphosate solution contained $140 \mathrm{~g}$ ae $\mathrm{L}^{-1}$.

b Marketable is the aggregate of jumbo, no. 1, and canner. cracks, folds, "elephant hide", malformation, and smallsized tubers when glyphosate was applied to potato. In contrast to the results of the present study, Felix et al. (2011) reported that potato tuber injury severity increased with increasing glyphosate drift dosage. Compared to the non-treated check, sweetpotatoes treated with glyphosate 4 WAP only had a greater percentage of cracked no. 1 and marketable sweetpotatoes (Table 4). Those treated $6 \mathrm{WAP}$ had a greater percentage of cracked jumbo, no. 1, and marketable sweetpotatoes. Sweetpotatoes treated 4, 6, and 8 WAP had a greater percentage of cracked canner and marketable sweetpotatoes. These results are similar to those of Meyers et al. (2016), who reported that sweetpotato plots wicked once 7 WAP had a greater percentage of cracked no. 1 storage roots, and that sweetpotatoes wicked sequentially at 4 and 7 WAP had a greater percentage of cracked marketable storage roots than did the non-treated check.

Because environmental and cultural conditions differed each year, the authors are uncertain why root cracking data were influenced by treatment in 2009 but not in 2014. It is plausible that the effect of variety is responsible for a portion of this difference. Covington was planted in 2009 and Beauregard in 2014. Covington has been documented to be more susceptible to abiotic stressors. Dittmar et al. (2013) reported that Covington displayed greater storage root injury than Beauregard in response to halosulfuron-methyl applications, and that applications made 22 and 31 DAP to Covington resulted in unacceptable incidence of black blistering on the skin and red-brown spots on the flesh. When treated with ethephon (2-chloroethylphosphonic acid),

Table 4. Effect of simulated glyphosate drip timing on sweetpotato storage root cracking injury at Clinton, North Carolina in 2009.

\begin{tabular}{|c|c|c|c|c|}
\hline \multirow[b]{2}{*}{ Drip timing $^{a}$} & \multicolumn{4}{|c|}{ Percent of yield cracked (by weight) } \\
\hline & Jumbo & No. 1 & Canner & Marketable $^{\mathrm{b}}$ \\
\hline $\mathrm{WAP}^{\mathrm{c}}$ & & 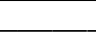 & $\%$ & \\
\hline Non-treated & 0 & 0 & 0 & 0 \\
\hline 4 & 12 & 16 & 9 & 15 \\
\hline 6 & 20 & 22 & 8 & 19 \\
\hline 8 & 8 & 5 & 2 & 6 \\
\hline $4 \mathrm{fb} 6 \mathrm{fb} 8$ & 7 & 10 & 13 & 16 \\
\hline LSD $(\mathrm{P} \leq 0.05)$ & 18 & 15 & 12 & 11 \\
\hline
\end{tabular}


Covington also had greater incidence and severity of internal necrosis, a physiological disorder in sweetpotato that results in brown to black flesh at the proximal end of the storage root, than did Beauregard (Clark et al. 2013).

The present study utilizes a worst-case scenario in which all sweetpotato plants in a plot are subjected to simulated off-target glyphosate drip. In a production environment it is highly unlikely that every plant would be exposed to 2 to 6 drops of herbicide solution. Additionally, the impact on overall production within a field may not be as extreme as our results suggest. If a sweetpotato plant in a commercial production setting is exposed to an off-target glyphosate drip and is stunted or killed, adjacent plants will quickly fill in that void and benefit from additional light, water, and nutrient resources that would have been used by the affected plant. The impact of sweetpotato injury on the yield of adjacent uninjured rows was not measured in the present study. However, Main and Thompson (2000) reported that when a single sweetpotato plant was missing, plants in the same row and next to the missing plant tended to have greater yields of all grades of sweetpotato.

Sweetpotato tolerance to simulated glyphosate drip increased the longer plants were established prior to glyphosate exposure. However, given that the sweetpotato critical period for weed control is from 2 to 8 WAP (Seem et al. 2003), waiting to wick upright weeds until 8 WAP will result in increased sweetpotato yield loss due to competition prior to and between wicking applications (Coleman 2014; Meyers et al. 2016). To limit sweetpotato crop injury and subsequent yield loss, wicking equipment should be maintained in a way that limits the risk of herbicide solution dripping onto sweetpotato vines.

\section{Literature Cited}

Clark CA, da Silva WL, Aranibia RA, Main JL, Schutlheis JR, Pesic-vanEsbroeck Z, Jiang C, Smith J (2013) Incidence of end rots and internal necrosis in sweetpotato affected by cultivar, curing, and ethephon defoliation. HortTechnology 23: 886-897

Coleman LB (2014). Stale Seedbed Manipulation, Increased Rates of Flumioxazin, and Wick Applied Herbicides for Palmer Amaranth Control in 'Covington' Sweetpotato. MS thesis. Raleigh, NC: North Carolina State University. 77 p

Dittmar PJ, Monks DW, Jennings KM, Schultheis JR (2013) Effects of halosulfuron POST on sweetpotato yield and storage root quality. Weed Technol 27:113-116
Felix J, Boydston R, Burke IC (2011) Potato response to simulated glyphosate drift. Weed Technol 25:637-644

Felix J, Boydston R, Burke IC (2012) Response of direct-seeded dry bulb onion to simulated glyphosate drift with variable rates and application timings. Weed Technol 26:747-756

Gilreath JP, Chase CA, Locascio SJ (2000) Phytotoxic effects of glyphosate on pepper (Capsicum annuum). Weed Technol 14:488-494

Kemble JM, ed (2015) Southeastern U.S. 2015 Vegetable Crop Handbook. Lincolnshire: IL: Vance Publishing Corp. p 271

MacRae AW (2005) Evaluation of Halosulfuron, Thifensulfuron, and Trifloxysulfuron Herbicides for Their Use in Sweetpotato. PhD dissertation. Raleigh, NC: North Carolina State University. $90 \mathrm{p}$

MacRae AW, Monks DW, Batts RB, Thornton AC (2007a) Sweetpotato tolerance to thifensulfuron applied postemergence. Weed Technol 21:928-931

MacRae AW, Monks DW, Batts RB, Thornton AC, Schultheis JR (2007b) Sweetpotato tolerance to halosulfuron applied postemergence. Weed Technol 21:993-996

Main JL, Thompson PG (2000) Missing plants in sweetpotato. HortScience 35:569

McNaughton KE, Sikkema PH, Robinson DE (2012) Response of processing tomato to simulated glyphosate drift followed by in-crop metribuzin application. Weed Technol 26:757-762

Meyers SL, Jennings KM, Monks DW (2014) 'Covington' sweetpotato tolerance to flumioxazin applied POST-directed. Weed Technol 28:163-167

Meyers SL, Jennings KM, Monks DW, Miller DK, Shankle MW (2013) Rate and application timing effects on tolerance of Covington sweetpotato to $S$-metolachlor. Weed Technol 27:729-734

Meyers SL, Jennings KM, Schultheis JR, Monks DW (2016) Evaluation of wick-applied glyphosate for Palmer amaranth (Amaranthus palmeri) control in sweetpotato. Weed Technol 30:765-772

Santos BM, Gilreath JP, Esmel CE, Siham MN (2007) Effects of sublethal glyphosate rates on fresh market tomato. Crop Protect 26:89-91

Seem JE, Creamer NG, Monks DW (2003) Critical weed-free period for 'Beauregard' sweetpotato (Ipomoea batatas). Weed Technol 17:686-695

[USDA] US Department of Agriculture (2005) United States Standards for Grades of Sweet Potatoes. Washington, DC: US Department of Agriculture

Webster TM (2014) Weed survey-southern states. Page 292 in Proceedings of the 67th Southern Weed Science Society. Birmingham, AL: Southern Weed Science Society

Received May 3, 2016, and approved August 25, 2016.

Associate Editor for this paper: Peter J. Dittmar, University of Florida.

Meyers et al.: Glyphosate Drip on Sweetpotato • 135 